\title{
CRESCIMENTO AGRÍCOLA NO PERÍODO 1999/2004: A EXPLOSÃO DA SOJA E DA PECUÁRIA BOVINA E SEU IMPACTO SOBRE O MEIO AMBIENTE*
}

\author{
Antonio Salazar Pessoa Brandão ${ }^{\S}$ \\ Gervásio Castro de Rezende \\ Roberta Wanderley da Costa Marques ${ }^{\dagger}$
}

\begin{abstract}
RESUMO
Este trabalho analisa o crescimento agrícola brasileiro após a mudança da política cambial, em janeiro de 1999. Toma como base, para isso, o comportamento da taxa de câmbio e dos preços internacionais das commodities ao longo do período 1999/2004. Discute-se, também, o comportamento da área cultivada nesse período recente, mostrando que ocorreu um aumento muito grande da área plantada com grãos nos anos agrícolas 2001/02, 2002/03 e 2003/04, em grande parte devido à expansão da soja. O trabalho propõe que essa expansão tão rápida da área plantada com soja se deu preponderantemente com base em conversão de pastagens. Sugere-se, ainda, que a expansão da soja não deve ser vista como antagônica à política ambiental, especialmente no que se refere à proteção da floresta amazônica.
\end{abstract}

Palavras-chave: crescimento agrícola, taxa de câmbio, preços internacionais, meio ambiente.

\begin{abstract}
This paper analyses the Brazilian agricultural growth since January 1999, when a new exchange rate policy was adopted by the country. The analysis focuses on the behavior the exchange rate and international commodity prices throughout the period 1999/2004. It is also analysed the behavior of cropped area in this recent period, with the conclusion that there has been a fast increase in area planted with grains in the agricultural years 2001/02, 2002/03 and 2003/04, due almost entirely to the growth of soybeans area. The paper proposes that this expansion of area planted with soybeans was based preponderantly on the conversion of pastures. It is also suggested that expansion of soybeans should not be seen as antagonistic to the environmental policy, specially in what respects the protection of the Amazon forest.
\end{abstract}

Key words: agricultural growth, exchange rate, international prices, environment.

JEL classification: Q18.

\footnotetext{
* Esta é uma versão revista de trabalho de mesmo título publicado pelo IPEA, em janeiro de 2005, como Texto para Discussão ${ }^{\circ}$ 1062. Os autores agradecem os comentários recebidos de dois referees desta revista, que muito contribuíram para delimitar mais e melhorar o artigo.

$\S \quad$ Professor de Economia da UERJ. E-mail: abrandao@firjan.org.br.

a Pesquisador Associado do IPEA e Professor Visitante da UERJ. E-mail: grezende@ipea.gov.br.

$\dagger$ Engenheira Agrônoma, Mestre em Economia Aplicada pela ESALQ/USP e ex-Assistente de Pesquisa do IPEA. E-mail: roberta.m@desiderata.org.br.

Endereço para contato: IPEA - Av. Pres. Antonio Carlos 51 - 15º andar - Rio de Janeiro (RJ) - CEP 20020-010.

Recebido em janeiro de 2005. Aceito em agosto de 2005.
} 


\section{INTRODUÇÃO}

Este trabalho tem por objetivo apresentar uma análise do processo de crescimento da agricultura brasileira após a mudança da política cambial de janeiro de 1999. Embora seja claro que essa mudança de política econômica deve ter afetado muito favoravelmente o setor agrícola, não há, na literatura, uma análise mais detalhada de como isso se deu, especialmente quando se considera, simultaneamente, o comportamento dos preços agrícolas internacionais.

A análise se baseia no fato de que preços internacionais em queda anularam, parcialmente, o estímulo derivado da mudança cambial de 1999, mas, em compensação, uma fase de alta desses preços internacionais, a partir de 2002, reforçou o estímulo cambial, do que resultou uma fase de grande dinamismo para a agricultura brasileira, principalmente nos últimos três anos agrícolas.

Verificou-se, também, que a expansão agrícola recente se caracterizou por um aumento muito rápido, de nada menos do que $22,8 \%$, da área plantada com grãos, ao longo de apenas três anos agrícolas (2001/02, 2002/03 e 2003/04). Nisto, essa expansão recente difere radicalmente do padrão que prevaleceu durante toda a década de 1990, em que a área agrícola total com lavouras permaneceu constante e todo o aumento da produção agrícola vegetal veio de aumentos de produtividade da terra. Esta expansão recente de área se deu sobretudo na soja, que cresceu, somente nesses três anos agrícolas, 39,8\% nas regiões Sul-Sudeste e nada menos que 66,1\% na região Centro-Oeste.

À primeira vista poder-se-ia dizer que o crescimento da produção agrícola vegetal recente terse-ia dado, parafraseando Ricardo, de forma "extensiva”, e não mais "intensiva”, como antes. Entretanto, como esse processo recente de expansão de área plantada parece ter-se dado, preponderantemente, com base em conversão de pastagens, é possível dizer, afinal de contas, que essa expansão recente de área plantada "intensifica" ainda mais o processo de crescimento agrícola brasileiro, ao contrário do que parece à primeira vista.

Assim, após admitir que a rápida expansão recente de área plantada se deu muito mais à base de conversão de pastagens do que de abertura contemporânea de novas áreas - seja no cerrado, seja na floresta amazônica -, o trabalho sugere a hipótese de que isto foi viabilizado, também, pela maior facilidade de aquisição, por parte dos agricultores, de máquinas e implementos agrícolas a partir do ano agrícola 2000/01, graças ao Programa de Modernização da Frota de Tratores e Máquinas Agrícolas (o Moderfrota).

O trabalho aproveita para também apresentar o argumento de que o crescimento da produção de soja não deve, de qualquer maneira, ser visto como antagônico à política ambiental, especialmente no que se refere à floresta amazônica. Como parte dessa argumentação, o trabalho defende o asfaltamento, o mais rapidamente possível, da BR 163, já que, independentemente do efeito benéfico, via redução de custo de transporte, que esse asfaltamento trará, essa melhoria de infra-estrutura viabilizará o plantio de soja no entorno dessa estrada e permitirá que a política de preservação ambiental do governo seja mais eficiente do que ela é hoje.

O trabalho está assim organizado. Na próxima seção será apresentada uma breve análise do comportamento dos preços agrícolas domésticos no período 1998/2004, procurando identificar os efeitos separados da taxa de câmbio e dos preços internacionais, em cada conjuntura. A seção

1 A respeito dessa conexão entre a expansão agrícola e a intensificação da pecuária, os autores devem muito à insistência do Prof. Guilherme Dias, da USP, que, em mensagem a um dos autores, propôs que "a unidade de área que deveríamos medir é uma de rotação entre milho/soja/pastagem (...)." Deve-se advertir o leitor, contudo, que a expansão recente de área com soja não deve ser considerada parte do processo em curso de "integração lavoura-pecuária”, devido à rapidez (verdadeira "explosão") desse crescimento da área com soja, e também devido ao fato de que o plantio de soja para renovação de pastagens é um fenômeno muito comum no Brasil, sobretudo nos cerrados, como será esclarecido depois. Sobre este tema da integração lavoura-pecuária, ver as matérias "Dupla Aptidão", do Globo Rural n 229, de Novembro de 2004, e "Reintegração de Produtividade", da revista Panorama Rural n 70, de Novembro de 2004. 
3 mostra o grande aumento ocorrido na área cultivada total a partir do ano agrícola 2001/02, em franco contraste com a estagnação que ocorreu na área cultivada total ao longo de toda a década de 1990. A seção 4 sugere que essa expansão de área cultivada não exigiu um alargamento territorial da agricultura brasileira, e muito menos representou uma ameaça à preservação ambiental, uma vez que a expansão de área cultivada se deu, em sua maior parte, a expensas da conversão de pastagens, e em conjunto com uma rápida expansão da pecuária bovina no mesmo período. A seção 5 apresenta o argumento de que, ao contrário do que comumente se pensa, a soja deve ser vista, potencialmente, como "amiga" e não "inimiga" da preservação ambiental, inclusive no caso da floresta amazônica.

A seção 6 considera para análise adicional essa expansão recente da área total cultivada com grãos no Brasil. Propõe-se a hipótese de que essa expansão de área se beneficiou do aumento e da renovação recentes do estoque de tratores e máquinas agrícolas no Brasil, graças ao Moderfrota, que teve suas operações iniciadas, precisamente, no ano de 2000.

A seção 7 apresenta um sumário e as conclusões do trabalho.

\section{O COMPORTAMENTO DOS PREÇOS AGRÍCOLAS DOMÉSTICOS NO PERÍODO 1999/2004: O PAPEL DA TAXA DE CÂMBIO E DOS PREÇOS INTERNACIONAIS ${ }^{2}$}

Como mostra o Gráfico 1, os preços dos produtos agrícolas vegetais, quando deflacionados por um índice geral de preços como o IPCA, mantiveram-se estáveis até pelo menos o segundo semestre de 2001; somente os preços dos produtos animais mostraram elevação como resultado da mudança da política cambial em janeiro de 1999. Na realidade, embora isto não seja mostrado aqui, esses preços dos produtos agrícolas vegetais sofreram uma queda significativa, quando deflacionados por um índice de preços de insumos agrícolas (IPP da FGV).

Gráfico 1 - Índices dos preços agrícolas domésticos e da taxa de câmbio efetiva real jan/98=100 (Deflator: IPCA)

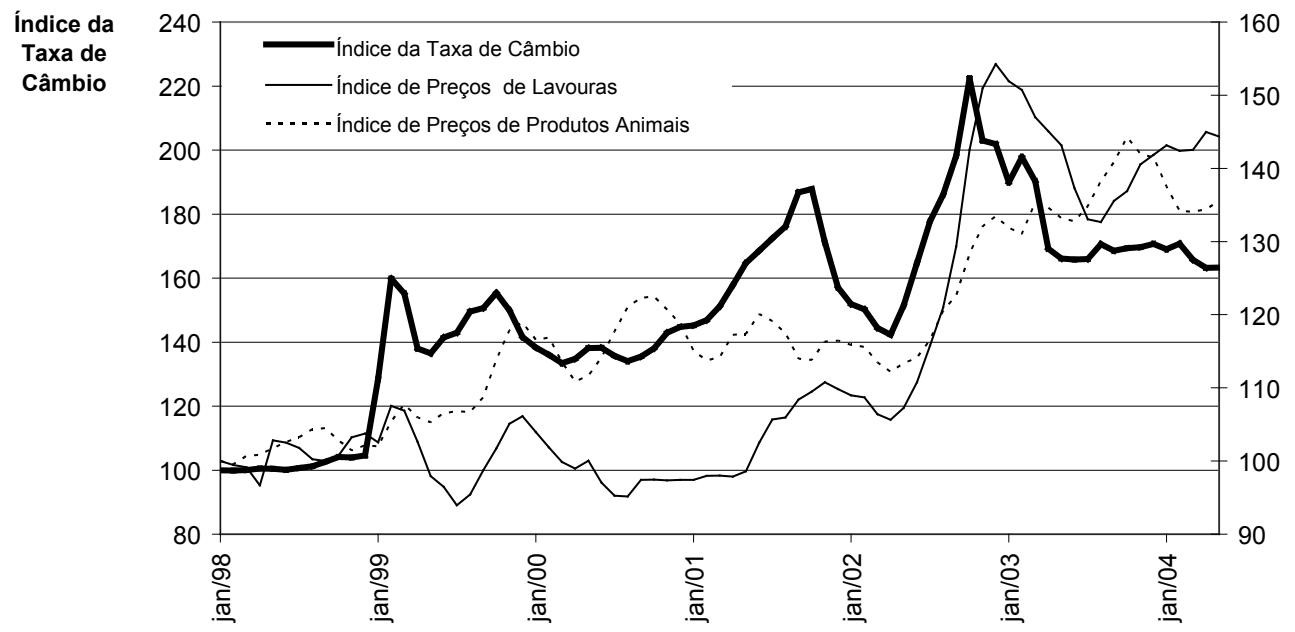

Índices de Preços Agrícolas Domésticos

Fonte: FGV e Ipeadata.

2 Esta seção é uma versão resumida da seção 2 de Brandão, Rezende e Marques (2005). 
Uma explicação para este fato é que exatamente no período que se seguiu à mudança da política cambial no Brasil ocorreu uma derrocada dos preços agrícolas no mercado internacional, conforme mostra o Gráfico 2, que apresenta o índice do Commodity Research Bureau (CRB) para grãos e oleaginosas. ${ }^{3}$ Essa derrocada, por sua vez, veio em seqüência a uma fase de preços agrícolas internacionais elevados, e mesmo de picos históricos, como aconteceu no biênio 1995-96.

Gráfico 2 - Evolução do índice crb para grãos e oleaginosas - jan/90=100 (Deflator: CPI)

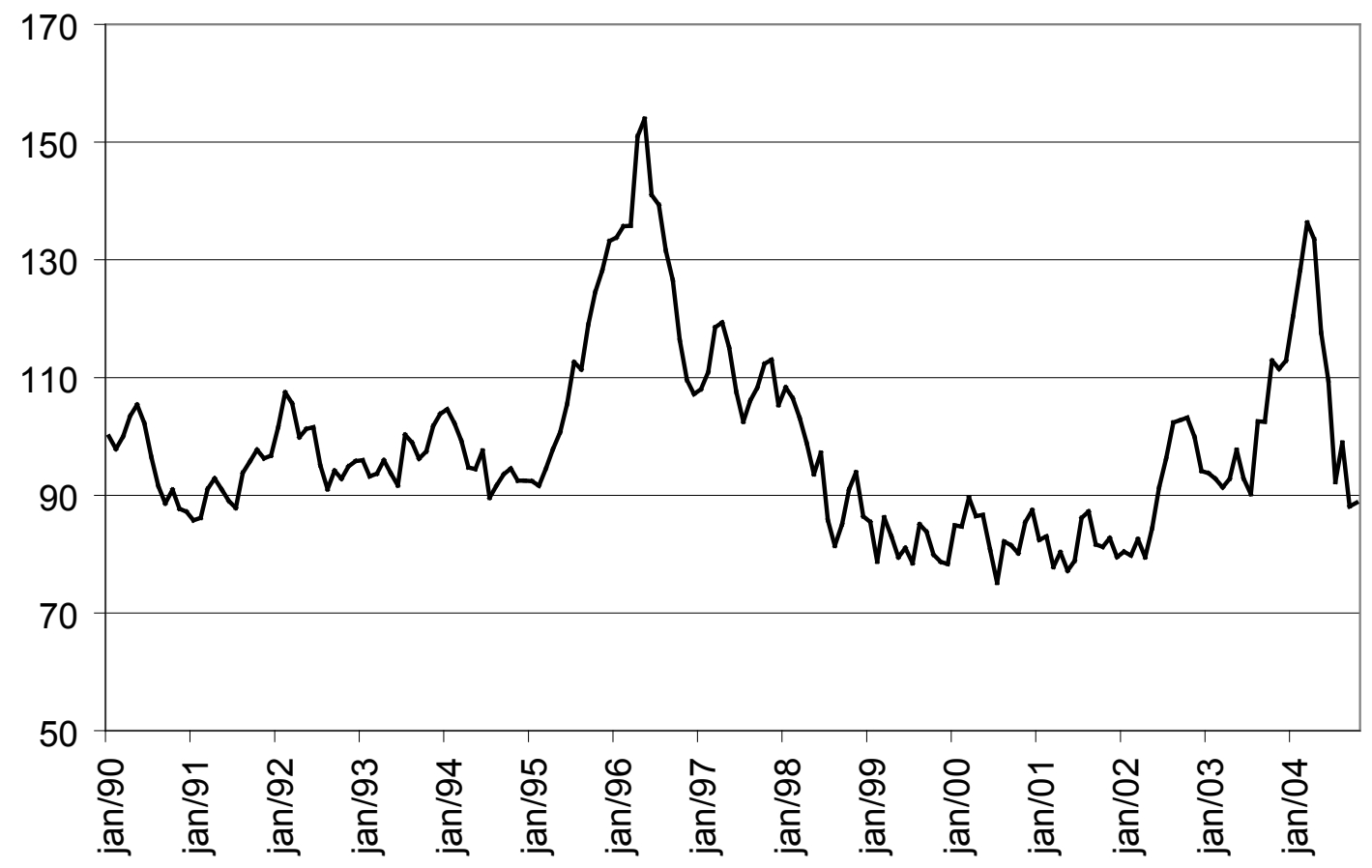

Fonte: Commodity Research Bureau (CRB).

O caso da soja serve para lançar luz sobre o comportamento dos mercados internacionais das commodities agrícolas. Conforme mostra o Gráfico 3, o preço internacional da soja manteve-se baixo ou em queda entre 1998 e 2001; somente a partir de 2002 esse preço inicia uma arrancada, num ciclo de alta que vai assumir seu pico no primeiro semestre de 2004 e depois despencar no segundo semestre de 2004.

Assim, em face da coincidência da liberalização cambial no Brasil com esse ciclo de baixa dos preços no mercado internacional dos grãos, pode-se afirmar que a desvalorização cambial de 1999 apenas impediu que houvesse uma queda nos preços domésticos nesse período, não tendo sido, assim, o ponto de partida da expansão agrícola recente, pelo menos no que concerne aos grãos. Esse ponto de partida foi provido pela recuperação dos preços internacionais dos grãos, a partir do ano agrícola 2001/02.

3 Note-se que os demais índices CRB de preços agrícolas apresentaram um comportamento similar ao do índice mostrado nesse Gráfico 2. 
Gráfico 3 - Índices dos preços domésticos e internacionais da soja e da taxa de câmbio efetiva real $-\mathrm{jan} / 98=100$

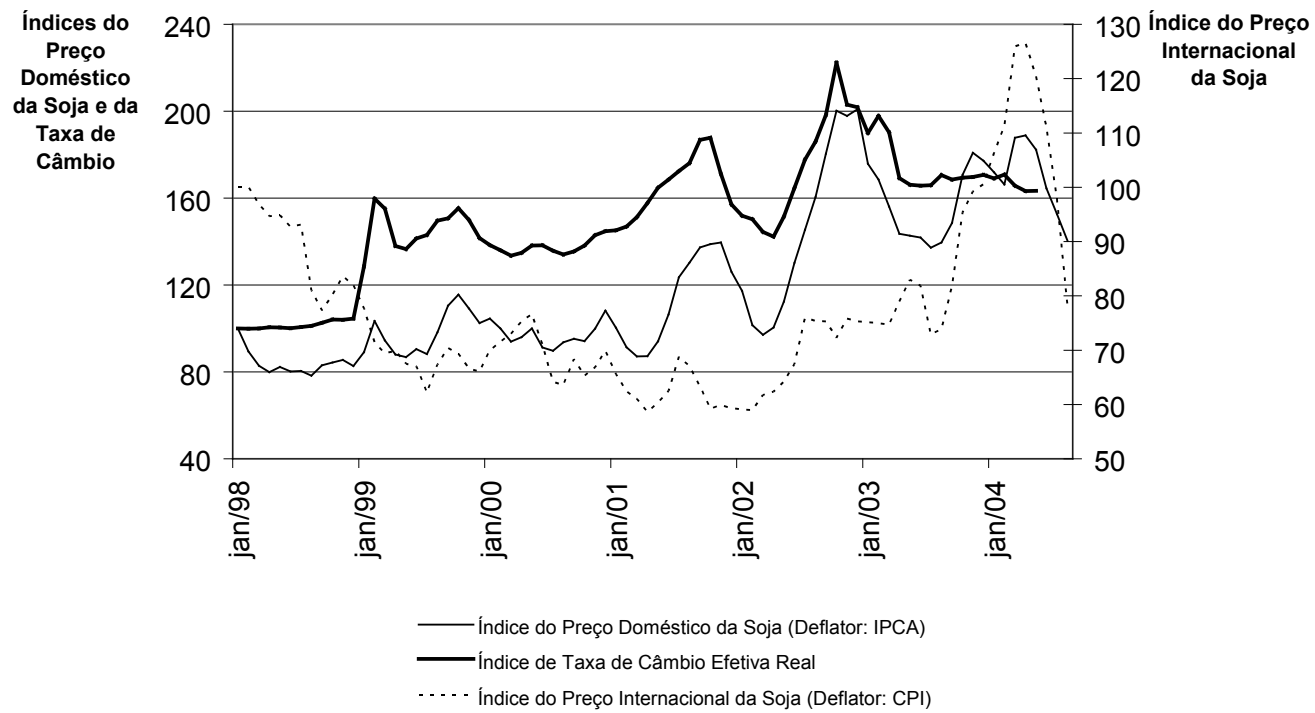

Fonte: Conab e Ipeadata.

O período 1998/2004 pode ser dividido, grosso modo, em dois períodos, em função do papel relativo da taxa de câmbio e dos preços internacionais na formação do preço doméstico da soja: 1) 1998/2001, em que a taxa de câmbio meramente impediu uma queda dos preços domésticos, e 2) 2002/2004, em que a taxa de câmbio pode deixar de cumprir esse papel devido à alta dos preços internacionais da soja.

A conjuntura mundial de preços de soja mudou radicalmente a partir do ano agrícola 2003/2004, e a menos que ocorram quebras de safra nos principais países produtores - Argentina, Brasil e Estados Unidos - é provável que os preços da soja permaneçam baixos, com conseqüente queda da rentabilidade agrícola e, possivelmente, uma crise financeira na agricultura brasileira, devido ao seu (provavelmente alto) nível de endividamento contraído na fase anterior de preços favoráveis. Neste cenário, o dinamismo observado nos anos recentes será reduzido substancialmente, a despeito da rentabilidade relativamente elevada da soja, mesmo em condições de preços menos favoráveis.

\section{O AUMENTO DA ÁREA PLANTADA COM LAVOURAS NO PERÍODO RECENTE, COM DESTAQUE ESPECIAL PARA O CASO DA SOJA}

O crescimento agrícola recente no Brasil se caracterizou por uma forte expansão da área total plantada, rompendo com um padrão de crescimento agrícola em que essa área cresceu muito pouco durante toda a década dos $1990 .^{4}$ Isto se nota especialmente no caso da soja, que registrou um aumento na taxa média anual de crescimento da área plantada de 3,6\% no período 1990/912000/01 para nada menos do que 13,8\% entre 2000/01 e 2003/04, conforme mostrado no Gráfico 4. Entretanto, a taxa de crescimento média anual da área total plantada com "outros grãos” (menos a soja) também mudou seu comportamento, passando de $-3,5 \%$ para $-0,7 \%$ na comparação dos dois

4 Note-se que esse fato foi assinalado em trabalho anterior de Brandão e Rezende (2004). 
períodos. Entretanto, o agregado da área total plantada com todas as lavouras (menos soja) praticamente não mudou seu comportamento no período.

Gráfico 4 - Índices de área plantada com soja e com agregados de lavouras, de 1990 a 2003

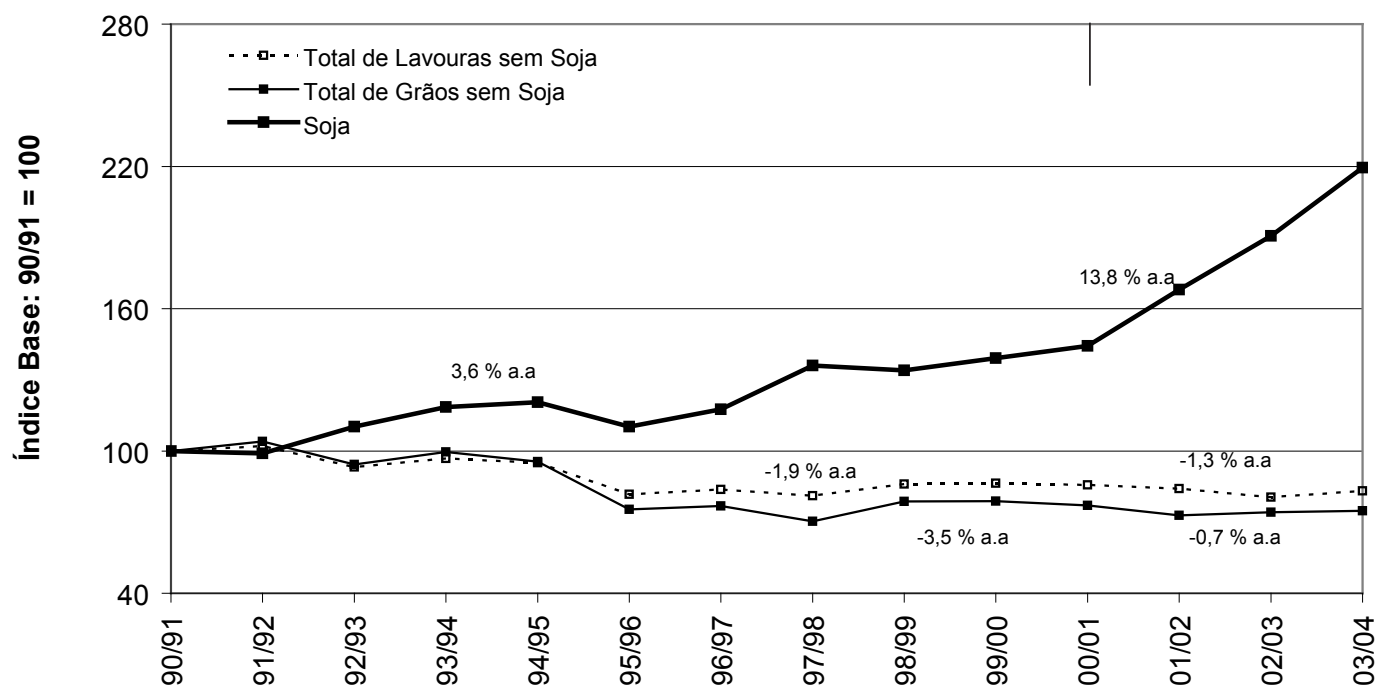

Fonte: IBGE e Conab.

Com o objetivo de analisar esse fenômeno recente do crescimento mais rápido da área cultivada no Brasil, apresentamos a Tabela 1, que mostra essa mudança de comportamento da soja, cuja área plantada cresceu, no período 1990/91-2000/01, apenas nas Regiões Centro-Oeste e Norte/Nordeste; no período recente, entretanto, a área plantada com soja passou a crescer em todas as regiões do Brasil. Essa Tabela 1 mostra, também, que o crescimento de área com soja na década de 1990, nas regiões Centro-Oeste e Norte-Nordeste, foi acompanhado de ampliação da área total com lavouras, já que as lavouras que concorrem com a soja (milho $1^{a}$ safra, algodão e arroz) não tiveram sua área reduzida. É também digno de nota que, em contraste com esse período mais recente, a área plantada com soja cresceu muito pouco nas regiões Sudeste e Sul durante a década de 1990, não obstante ter havido contração na área plantada com os demais grãos, nessas regiões.

Como mostra também a Tabela 1 , o crescimento recente da área plantada com soja, em todas as regiões do Brasil, implicou expansão da área total ocupada com lavouras, uma vez que não ocorreu redução significativa da área das culturas competidoras, exceto a do milho $1^{\text {a }}$ safra, que teve a área reduzida em cerca de um milhão de hectares. Note-se, ainda, que, conforme mostra a Tabela 2 (e era de se esperar), a expansão de área com a soja acabou contribuindo para a expansão de área de culturas que utilizam, no inverno, a mesma área antes utilizada pela soja, como o milho $2^{\mathrm{a}}$ safra, o trigo e mesmo o algodão.

Note-se que a expansão de área plantada com soja entre os anos agrícolas 1990/91 e 2000/01, restrita, em grande parte, como foi, às regiões Centro-Oeste e Norte-Nordeste, tampouco se valeu de ocupação de área cedida por culturas competidoras, como milho $1^{a}$ safra e algodão. Assim, área nova de lavoura foi formada, de alguma maneira, nessas regiões, para permitir essa expansão da soja. 
Tabela 1 - Área plantada e variação da área plantada entre anos agrícolas selecionados, segundo produtos e regióes

\begin{tabular}{|c|c|c|c|c|c|c|c|}
\hline \multirow{3}{*}{ Produtos } & \multirow{2}{*}{\multicolumn{3}{|c|}{ Área Plantada (em 1000 ha) }} & \multicolumn{4}{|c|}{ Variação Acumulada } \\
\hline & & & & \multicolumn{2}{|c|}{ entre 1990/91 e 2000/01 } & \multicolumn{2}{|c|}{ entre 2000/01 e 2003/04 } \\
\hline & $1990 / 91$ & $2000 / 01$ & $2003 / 04$ & ( em 1000 ha) & ( em \%) & ( em 1000 ha) & $(\mathrm{em} \%)$ \\
\hline $\begin{array}{l}\text { Soja } \\
\text { Centro Oeste }\end{array}$ & $\begin{array}{l}9.743 \\
2.946\end{array}$ & $\begin{array}{r}13.970 \\
5.760\end{array}$ & $\begin{array}{r}21.244 \\
9.568\end{array}$ & $\begin{array}{l}4.227 \\
2.813\end{array}$ & $\begin{array}{l}43,4 \\
95,5\end{array}$ & $\begin{array}{l}7.274 \\
3.808\end{array}$ & $\begin{array}{l}52,1 \\
66,1\end{array}$ \\
\hline Sul/Sudeste & 6.507 & 7.156 & 10.006 & 649 & 10,0 & 2.850 & 39,8 \\
\hline $\begin{array}{l}\text { Milho } 1^{\mathrm{a}} \text { safra } \\
\text { Centro Oeste }\end{array}$ & $\begin{array}{r}12.652 \\
1.519\end{array}$ & $\begin{array}{r}10.546 \\
1.206\end{array}$ & $\begin{array}{r}9.457 \\
758\end{array}$ & $\begin{array}{r}-2.106 \\
-313\end{array}$ & $\begin{array}{l}-16,6 \\
-20,6\end{array}$ & $\begin{array}{r}-1.089 \\
-448\end{array}$ & $\begin{array}{l}-10,3 \\
-37,2\end{array}$ \\
\hline Sul/Sudeste & 8.000 & 6.482 & 5.573 & -1.518 & $-19,0$ & -909 & $-14,0$ \\
\hline $\begin{array}{l}\text { Feijão } 1^{\mathrm{a}} \text { safra } \\
\text { Centro Oeste }\end{array}$ & $\begin{array}{r}1.881 \\
40\end{array}$ & $\begin{array}{r}1.285 \\
55\end{array}$ & $\begin{array}{r}1.371 \\
61\end{array}$ & $\begin{array}{r}-595 \\
16\end{array}$ & $\begin{array}{r}-31,7 \\
39,7\end{array}$ & $\begin{array}{r}86 \\
6\end{array}$ & $\begin{array}{r}6,7 \\
11,2\end{array}$ \\
\hline Sul/Sudeste & 1.473 & 859 & 896 & -614 & $-41,7$ & 37 & 4,3 \\
\hline Algodão & 1.939 & 868 & 1.069 & -1.070 & $-55,2$ & 200 & 23,0 \\
\hline Centro Oeste & 171 & 542 & 605 & 371 & 216,9 & 64 & 11,8 \\
\hline Sul/Sudeste & 935 & 173 & 167 & -762 & $-81,5$ & -6 & $-3,2$ \\
\hline Arroz & 4.233 & 3.249 & 3.598 & -984 & $-23,3$ & 349 & 10,7 \\
\hline Centro Oeste & 777 & 631 & 862 & -146 & $-18,8$ & 231 & 36,6 \\
\hline Sul/Sudeste & 1.821 & 1.326 & 1.392 & -494 & $-27,1$ & 66 & 4,9 \\
\hline Total das Lavouras Acima & 30.446 & 29.918 & 36.738 & -528 & $-1,7$ & 6.820 & 22,8 \\
\hline Centro Oeste & 5.452 & 8.193 & 11.854 & 2.741 & 50,3 & 3.660 & 44,7 \\
\hline Sul/Sudeste & 18.736 & 15.996 & 18.034 & -2.740 & $-14,6$ & 2.038 & 12,7 \\
\hline Milho 2a Safra & 800 & 2.426 & 3.668 & 1.627 & 203,5 & 1.242 & 51,2 \\
\hline Trigo & 2.146 & 1.710 & 2.727 & -436 & $-20,3$ & 1.017 & 59,5 \\
\hline Feijão $2^{\mathrm{a}}$ e $3^{\mathrm{a}}$ safras & 3.624 & 2.594 & 2.886 & -1.030 & $-28,4$ & 293 & 11,3 \\
\hline Total dos Grãos de Inverno* & 7.447 & 7.929 & 10.525 & 482 & 6,5 & 2.595 & 32,7 \\
\hline Total das Lavouras & 51.800 & 51.600 & 60.640 & -200 & $-0,4$ & 9.040 & 17,5 \\
\hline
\end{tabular}

(*) Total dos Grãos de Inverno inclui: milho $2^{\mathrm{a}}$ safra, feijão $2^{\mathrm{a}}$ e $3^{\mathrm{a}}$ safras, trigo, triticale, aveia, centeio, cevada, girassol, mamona e sorgo.

Fonte: CONAB e IBGE.

Tabela 2 - Quantidades exportadas de carne bovina segundo os países, 1995/2004 (em mil t equivalente-carcaça)

\begin{tabular}{lcccccc}
\hline Anos & Austrália & EUA & União Européia & Brasil & Demais Países & Total \\
\hline 1995 & 1.109 & 826 & 1.199 & 228 & 2.150 & 5.512 \\
1996 & 1.026 & 851 & 1.101 & 224 & 2.293 & 5.495 \\
1997 & 1.184 & 969 & 1.051 & 232 & 2.367 & 5.803 \\
1998 & 1.268 & 985 & 769 & 306 & 2.154 & 5.482 \\
1999 & 1.270 & 1.094 & 949 & 464 & 2.118 & 5.895 \\
2000 & 1.338 & 1.119 & 615 & 492 & 2.364 & 5.928 \\
2001 & 1.398 & 1.029 & 546 & 748 & 2.089 & 5.810 \\
2002 & 1.365 & 1.110 & 512 & 881 & 2.518 & 6.386 \\
$2003^{*}$ & 1.261 & 1.144 & 456 & 1.175 & 2.364 & 6.400 \\
$2004^{* *}$ & 1.300 & 1.207 & 440 & 1.370 & 2.617 & 6.934 \\
\hline
\end{tabular}

*Estimativa.

* Projeção.

Fonte: USDA. 


\section{A UTILIZAÇÃo TEMPORÁRIA dE ÁREAS COM PASTAGENS DEGRADADAS COMO FON- TE PRINCIPAL DO CRESCIMENTO RECENTE DA ÁREA DE SOJA NO BRASIL}

Quanto à origem dessa área nova plantada com soja, tanto na década de 1990 (em que, como vimos, essa expansão de área com soja ficou restrita à região Centro-Oeste) quanto no triênio 2001/02-2003/04 (em que ela se generalizou a todas as regiões brasileiras), a hipótese a ser defendida aqui é que se trata, preponderantemente, de conversão de pastagens "degradadas" e não de áreas "virgens", sobretudo de floresta amazônica.

Essa hipótese de que a área de plantio de soja vem se expandindo, em sua maior parte, por meio da conversão de pastagens degradadas foi também defendida por Müeller (2003), em sua análise do processo de expansão da soja no Centro-Oeste, durante a década de 1990. Em apoio a sua hipótese, Müeller (2003) mostrou que a expansão da área com soja na década de 1990 se deu, predominantemente, nas mesmas microrregiões que já concentravam o grosso da produção de soja no início da década de 1990; ou seja, não houve aumento significativo de produção de soja em qualquer região que já não tivesse sido "aberta” à soja no início da década.

Quanto à expansão da área com soja no triênio 2001/02-2003/04, que foi muito mais rápida do que ocorreu na década de 1990 e se generalizou a todas as regiões produtoras de soja no Brasil, cabe notar o seguinte. Em primeiro lugar, é muito difícil "abrir-se” área virgem de cerrado (e muito menos ainda de floresta amazônica!) e, no mesmo ano ou mesmo até num prazo maior, usar-se essa área nova na produção de soja. Em outras palavras, partindo-se de uma área virgem - de cerrado ou de floresta amazônica -, requer-se um número mínimo de anos para que uma área nova, adequada para a produção agrícola, seja “produzida” e depois usada na produção agrícola propriamente dita. ${ }^{6}$ Esta é uma afirmativa passível de verificação empírica. No caso do cerrado, não se exclui a hipótese de que, devido à excepcionalidade desse período recente em termos de rentabilidade da soja, tenham sido adotadas tecnologias capazes de encurtar para um ano a duração do tempo requerido para a produção de soja. ${ }^{7}$

Em segundo lugar, as áreas virgens de cerrado ou de floresta amazônica disponíveis não possuem a infra-estrutura necessária a uma atividade como a soja; o mesmo problema não ocorre, no entanto, com regiões já ocupadas com pecuária, já que essas últimas tendem a ser muito mais bem situadas do ponto de vista logístico.

Em terceiro lugar, ao contrário das áreas virgens, áreas ocupadas com pastagens são muito mais viáveis de serem convertidas em área com soja e, no próprio período em que se dá essa conversão, iniciar-se a produção de soja. A razão para isto é que boa parte do processo de produção de terra apropriada para o plantio de soja (como, por exemplo, a calagem), já ocorreu, em um momento anterior. A propósito, vale a pena informar que a área de pastagem plantada no Centro-Oeste predomina amplamente sobre a área de pastagem natural. Basta notar que, segundo os

5 É muito generalizada a crença de que a soja vem se expandindo principalmente à custa do desmatamento adicional de áreas de cerrado e de floresta amazônica. Sobre isso, ver, por exemplo, a matéria "Plantio de Soja Avança sobre Amazônia", no jornal $O$ Globo, 18/9/03, que se refere a matéria publicada no New York Times sobre o mesmo assunto. Ver também "Amazônia: A Soja Avança na Floresta", uma reportagem especial publicada no jornal O Estado de São Paulo em 26/10/03, assim como a reportagem "Produção de Soja Avança no Oeste do Pará”, publicada no jornal Gazeta Mercantil de 16/01/04. Ver também a reportagem "Asphalt and the Jungle", no The Economist de 24/7/04, p. 33-35.

6 Ver, a este respeito, Rezende (2003), onde, tomando por base Cunha et alii (1994), propõe-se um modelo formal de "produção" de terra agrícola no cerrado, no qual ocorre essa defasagem temporal entre a alocação de fatores para produzir a terra e a alocação de outros fatores - juntamente com a própria terra produzida anteriormente - para a produção agrícola propriamente dita.

7 André Pessoa, em comunicação pessoal aos autores, informou, de fato, que uma prática nova, induzida pelo preço alto da soja, foi adotada nesse período recente, permitindo uma maior rapidez nessa conversão do cerrado em área propícia ao plantio de soja. Segundo André, em seguida à derrubada do cerrado, "corrigia-se com forte calagem a acidez e corrigia-se os níveis de fósforo alguns meses antes do plantio e no plantio usava-se adubação pesada (500 kg/há) e como resultado obtinha-se de saída 40 sacos de soja por hectare. O investimento é alto, mas com soja aos preços dos últimos anos ainda era compensador." 
Censos Agropecuários, a área de pastagem plantada aumentou, entre 1970 e 1995/96, de 7 para 50 milhões de hectares; enquanto isto, a área de pastagem nativa caiu de 46 para 23 milhões de hectares, nesse mesmo período. Em comparação, a área com lavoura era de apenas 7 milhões de hectares em 1995/96. A disponibilidade de pastagens para serem convertidas em lavouras é, assim, quase infinita.

Last but not least, a utilização de área de pastagem degradada para aumentar o plantio de soja pode render também, após alguns anos - após a semeadura de capim -, uma área de pastagem mais produtiva, o que eleva a rentabilidade do investimento na produção de soja nessas áreas. Em outras palavras, a conversão de pastagens em plantação de soja pode ser temporária, tendo por objetivo final a produção de novas pastagens, o que eleva a rentabilidade dessa operação, comparada com a conversão de áreas virgens. Contribui para essa utilização da soja para a renovação das pastagens o fato de que a soja faz diminuir os gastos com fertilizantes, já que ela fixa o nitrogênio no solo. Aliás, a soja cumpre esse papel de "desbravadora" do cerrado também no caso de outras atividades, como o algodão, que costuma ser plantado apenas depois de alguns anos de plantio de soja.

Entretanto, somente pesquisas de campo poderão esclarecer as formas específicas como se viabiliza, na prática, essa utilização de pastagens degradadas em plantio de soja e, depois, a volta (ou não) dessa área à pecuária, na condição de melhores pastagens. Sabe-se ser muito freqüente o arrendamento da terra por parte do sojicultor, o que tem a vantagem de eximi-lo da necessidade de imobilização de capital na aquisição de terra. ${ }^{8}$ Além disso, o pecuarista normalmente não possui as máquinas agrícolas necessárias para realizar ele mesmo a renovação das pastagens. Entretanto, em uma conjuntura como o período sob análise, em que, como se verá em seguida, verificou-se euforia também na atividade pecuária, não se exclui a possibilidade de que o próprio pecuarista tenha promovido essa renovação das pastagens por meio do plantio de soja e tenha também encurtado o tempo envolvido nessa renovação de pastagens.

De fato, a atividade pecuária também viveu um clima de euforia, no período sob análise. Conforme mostra o Gráfico 5, o preço doméstico do boi gordo beneficiou-se amplamente da desvalorização cambial de 1999, e acompanhou estreitamente as flutuações da taxa de câmbio desde então. De maneira consistente com isto, a Tabela 2 mostra que o Brasil teve um desempenho simplesmente espetacular no mercado internacional de carnes nesse mesmo período, passando a maior exportador mundial de carne bovina em 2004. Finalmente, o Gráfico 6 mostra que esse ganho na exportação de carne bovina não se fez à custa do mercado doméstico, já que o abate bovino aumentou também, de maneira significativa, no mesmo período.

8 A cessão de terra em arrendamento para a produção de grãos (algodão, arroz, milho e soja) e, no final, renovação de pastagens é um fenômeno antigo e muito comum nas regiões de cerrado. Uma análise detalhada desse fenômeno é apresentada em Romeiro e Reydon (1994). Ver, também, a interessante entrevista concedida à revista Agroanalysis de novembro de 2002 por Humberto Guimarães, criador da "Bolsa de Arrendamento" de Uberaba (MG). 
Gráfico 5 - Brasil - Índices do preço do boi gordo e da taxa de câmbio (deflator: IPCA; base: jan. $96=100)$

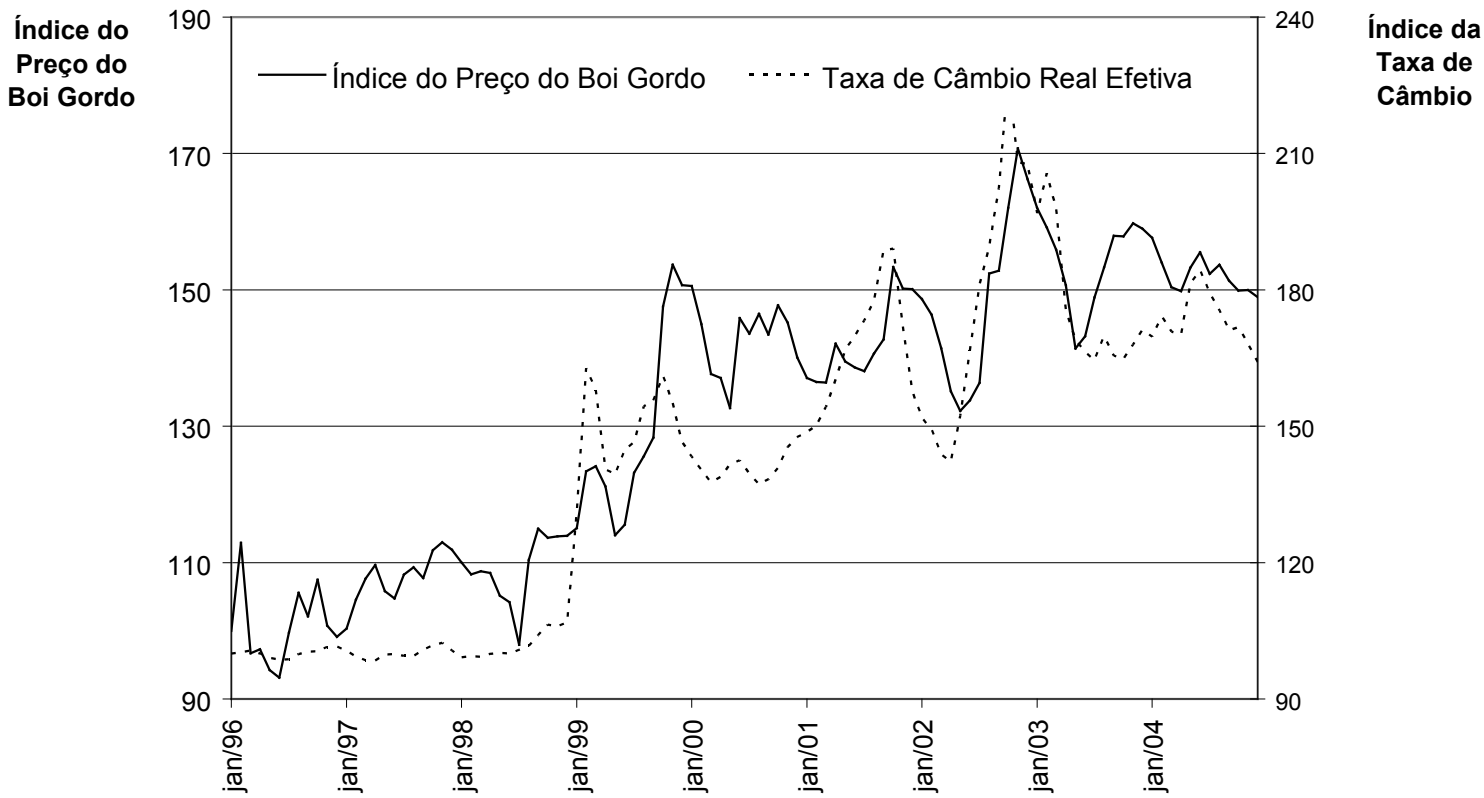

Gráfico 6 - Brasil - evolução do número de bovinos abatidos, 1997/2005 (dados dessazonalizados)

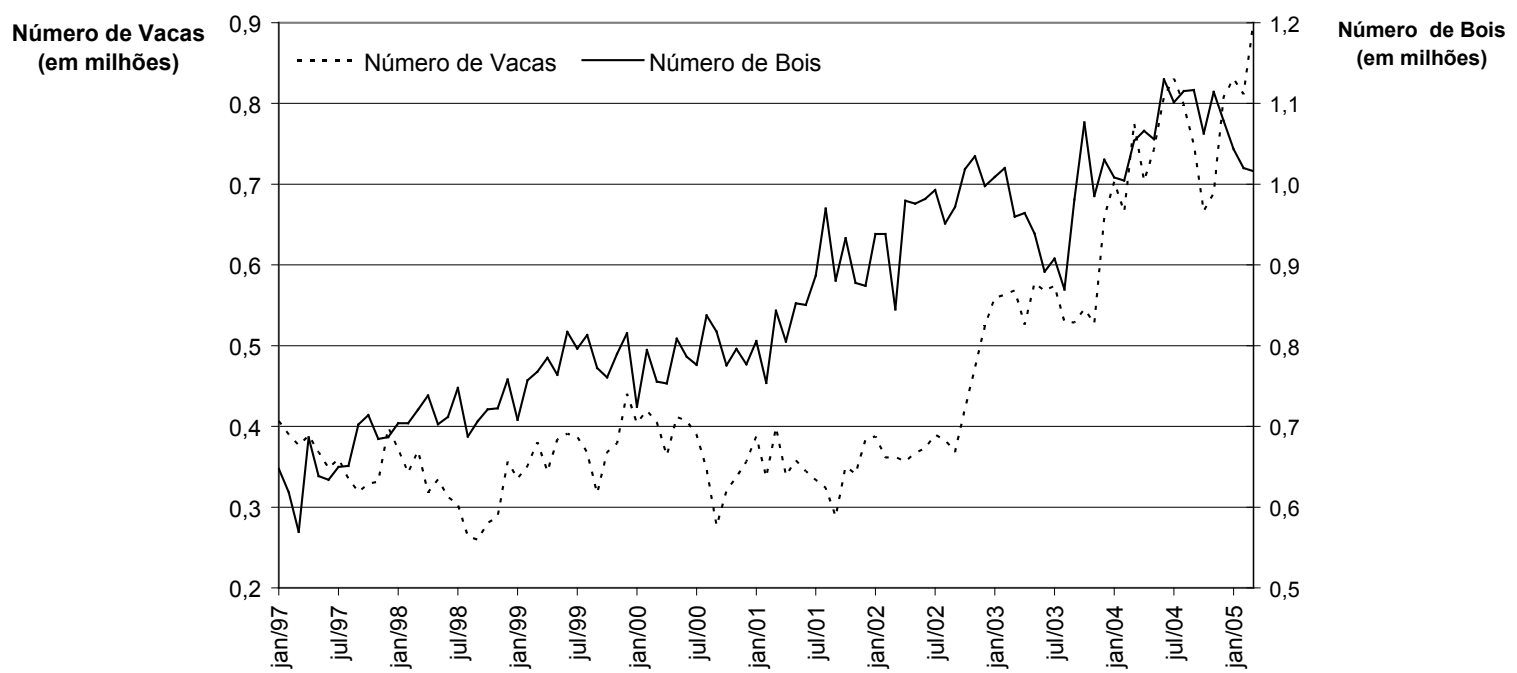

Fonte: IBGE.

É interessante notar ainda, nesse Gráfico 6, o grande aumento ocorrido no abate de vacas a partir de 2002. Segundo Abou Nehmi Filho, conhecido especialista em pecuária no Brasil, isso foi causado pela necessidade de diminuição do tamanho do rebanho, já que a disponibilidade de pastagens tinha se reduzido temporariamente, dentro desse processo recente de renovação de pastagens no Brasil. ${ }^{9}$

9 Veja a entrevista de Abou Nehmi Filho, na reportagem "Boi versus Soja”, no Globo Rural n. 223, maio de 2004. 
De maneira plenamente consistente com esses indicadores positivos de desempenho da pecuária bovina no Brasil, a Tabela 3 mostra que o estoque de gado no Brasil aumentou a sua taxa de crescimento anual de 1,1\% aa, no período 1990-1999, para nada menos de 4,3\% aa, no período 19992003. Essa expansão recente do rebanho bovino no Brasil, que reflete, naturalmente, o aumento da rentabilidade da pecuária, é fruto da melhoria genética que vem ocorrendo no setor, a qual se completa com a melhoria de pastagens. Esse aumento do rebanho deve, assim, ser considerado mais uma evidência em favor da hipótese proposta neste trabalho, de que a expansão da área com soja se baseou, preponderantemente, em renovação de pastagens.

Tabela 3 - Brasil e regiões: evolução do rebanho bovino no período 1990/2003 e taxas de crescimento médio anual nos períodos 1990/99 e 1999/2003 (em milhões de cabeças)

\begin{tabular}{ccccccc}
\hline Ano & Brasil & Centro-Oeste & Norte & Sudeste & Sul & Nordeste \\
\hline 1990 & 147,1 & 45,9 & 13,3 & 36,3 & 25,3 & 26,2 \\
1991 & 152,1 & 48,1 & 15,4 & 36,7 & 25,3 & 26,7 \\
1992 & 154,2 & 48,8 & 15,8 & 37,2 & 25,5 & 26,9 \\
1993 & 155,1 & 52,2 & 17,1 & 37,6 & 25,7 & 22,5 \\
1994 & 158,2 & 53,4 & 18,0 & 37,6 & 26,4 & 22,8 \\
1995 & 161,2 & 55,1 & 19,2 & 37,2 & 26,6 & 23,2 \\
1996 & 158,3 & 53,4 & 18,0 & 36,6 & 26,4 & 23,9 \\
1997 & 161,4 & 54,6 & 19,3 & 37,0 & 26,7 & 23,8 \\
1998 & 163,2 & 56,4 & 21,1 & 37,1 & 26,6 & 22,0 \\
1999 & 164,6 & 57,2 & 22,4 & 36,9 & 26,2 & 21,9 \\
2000 & 169,9 & 59,6 & 24,5 & 36,9 & 26,3 & 22,6 \\
2001 & 176,4 & 61,8 & 27,3 & 37,1 & 26,8 & 23,4 \\
2002 & 185,3 & 65,6 & 30,4 & 37,9 & 27,5 & 23,9 \\
2003 & 195,6 & 69,9 & 33,9 & 38,7 & 28,0 & 25,0 \\
\hline \multicolumn{7}{r}{ Taxa de Crescimento Médio Anual (\%) } \\
\hline $1990 / 99$ & 1,1 & 4,3 & 0,1 & \\
$1999 / 03$ & 4,3 & 4,9 & 10,4 & 1,2 & 1,8 & $-2,0$ \\
\hline
\end{tabular}

Fonte: Pesquisa Pecuária Municipal- IBGE.

É interessante notar também que, em trabalho recente, o USDA chamou a atenção para essa grande capacidade que o Brasil dispõe de aumentar a área de lavouras por meio de conversão de pastagens, o que foi considerado uma circunstância que favorece a competitividade internacional do nosso País vis-à-vis aos Estados Unidos. ${ }^{10}$

É interessante notar, finalmente, que Torres Jr. et alii (2004, p. 37) estimam que esse processo de conversão de área de pastagens tenha envolvido cerca de 4,9 milhões de hectares no triênio 2001/2003 e mais 3,0 milhões de hectares somente em 2004. ${ }^{11}$ Note-se que esses números são da mesma ordem de grandeza dos 6,8 milhões de hectares de aumento da área total plantada com grãos no Brasil nos anos agrícolas 2001/02, 2002/03 e 2003/04, como mostrado na Tabela 1.

Essa evidência de expansão da pecuária de corte é consistente com a hipótese proposta neste trabalho, de que a conversão de pastagens degradadas não se estaria dando em detrimento da pecuária, mas, muito ao contrário, seria um mecanismo por meio do qual a pecuária estaria conse-

10 Ver Shean (2003).

11 Em sua comunicação aos autores, entretanto, André Pessoa informou que, segundo suas estimativas, a área de pastagens convertida em plantio de soja foi de 3,8 milhões de hectares nos últimos três anos. Embora inferior à expansão total da área com soja, ainda assim é uma área muito grande, sobretudo considerando o curto período de tempo envolvido. 
guindo renovar suas pastagens, com conseqüente aumento da capacidade de lotação dos pastos no futuro.

Assim, a conjugação de preços favoráveis tanto para a soja como para a pecuária bovina fez aumentar, ao mesmo tempo, a demanda e a oferta de áreas de pastagens para o cultivo de soja. Em especial, o aumento da produção de soja via arrendamento temporário de terras antes ocupadas com pastagens é, claramente, um mecanismo não só agronomicamente consistente com o objetivo de produção rápida da soja (tendo em vista aproveitar uma conjuntura favorável de preços), como também economicamente mais adequado do que as alternativas de aumento da produção de soja via substituição definitiva de pastagens ou conversão de áreas virgens, já que, dessa forma, o setor agrícola pode reduzir a imobilização de capital, tornando-se, assim, mais capaz de conviver com a volatilidade dos mercados internacionais dos grãos. ${ }^{12}$

Não se exclui, naturalmente, a possibilidade de que áreas de floresta amazônica ou de cerrados, que tivessem iniciado, em anos anteriores a esse período de expansão recente, seu processo de conversão em terra agrícola, possam também ter servido de fonte para a expansão recente da área plantada com soja.

Note-se que também nas regiões Sul e Sudeste ocorreu expansão rápida da área de soja no último triênio, após o fraco crescimento da área durante a década de 1990. Evidentemente, ninguém iria propor que essa expansão recente da soja nessas regiões tenha se baseado em áreas ainda virgens, já que essas simplesmente não mais existem nessas regiões. Como tampouco ocorreu substituição de culturas nessas regiões, a conversão de pastagens é a única possibilidade que pode ser admitida para explicar essa mudança radical no uso da terra no Sul e no Sudeste.

Com relação ao Centro-Oeste, cabe notar que, especialmente no caso do Mato Grosso, essa grande região dispõe de áreas muito amplas, atualmente ocupadas com pecuária extensiva, fruto do grande desmatamento promovido nos governos militares, como decorrência dos projetos de colonização e da ocupação desenfreada da Amazônia. Isto inclui especialmente o assim chamado "Nortão" de Mato Grosso. Um caso particularmente interessante, a este respeito, é o do município de Querência, em que a soja passou a ser produzida só recentemente, e totalmente à base de conversão de pastagens degradadas, formadas muito antes desse recente "boom" da soja. ${ }^{13}$ Um outro caso similar ao de Querência é o do Vale do Araguaia, discutido em Müeller (2003). Estes exemplos de Querência e do Vale do Araguaia deixam muito claro que não é suficiente constatar - por meio, por exemplo, de fotografias aéreas - que a área de soja vem se expandindo nesse Nortão para então se concluir que a floresta amazônica ou as áreas remanescentes de cerrado estão sendo ameaçadas pela soja.

É preciso ter presente, aliás, que nosso argumento de que é impossível abrir uma área de floresta amazônica, e em um ou dois ou até em três anos conseguir semear a soja, se restringe à floresta densa, que é a que consideramos, mais propriamente, "floresta amazônica”, ao contrário da prática muito comum de se considerar "floresta amazônica" toda floresta ou mata que esteja dentro da Amazônia Legal, um conceito puramente administrativo e que não deveria servir de base para análises de meio ambiente e de aptidão agrícola. Aliás, em matéria de aptidão agrícola para a soja, a floresta amazônica (no sentido estrito acima) não tem, até agora, revelado aptidão

12 A expansão de soja via conversão de pastagens e não de abertura de áreas virgens de cerrado tem sido defendida como mais adequada do ponto de vista da preservação da biodiversidade; sobre isto, ver Abramovay (1999). Nessa proposta, contudo, como a conversão de pastagens em área de soja tomaria um caráter permanente, ela implicaria um custo de oportunidade maior do que o existente na conversão de terra virgem de cerrado, conforme apontado em Rezende (2003, p. 202-3).

13 As drásticas mudanças no uso da terra em curso no caso de Querência foram objeto da reportagem intitulada "Mapa Redesenhado", publicada no Globo Rural de agosto de 2004, p. 12/16. Segundo essa matéria, a área plantada com soja (que era praticamente nula antes dessa expansão recente) passou a ser de 65 mil hectares em 2002/03, subiu para 113 mil hectares em 2003/04, e é esperada aumentar para nada menos do que 180 mil hectares em 2004/05. Note-se que essa forte expansão de soja foi toda baseada em conversão de pastagem, sem ter requerido um único hectare de terra desmatada de cerrado ou de floresta amazônica. 
agrícola para lavouras - incluindo, em especial, a soja -, exceto em áreas bem restritas. Contribui para isso não só a pobreza dos solos, mas também o clima inadequado, especialmente no que tange à pluviometria.

Em decorrência desse conceito restrito de "floresta amazônica" adotado aqui, fica excluído dessa classificação, em particular, o Nortão do Mato Grosso, que, exatamente por não ser nem totalmente cerrado nem totalmente floresta amazônica, sempre foi chamado de "Zona de Transição". Isto é como deveria ser, pois que "natura non facit saltum", o que significa que um bioma não se transforma em outro abruptamente, havendo todo um processo lento e imprevisível de mudança no espaço. O mesmo, aliás, acontece com as estações do ano, que só mudam - agora ao longo do tempo - de maneira muito lenta e geralmente de modo também imprevisível. Esta é a razão de por que esse Nortão inclui municípios como Sorriso, o maior produtor de soja no Brasil, e cuja vegetação, pluviometria, tipo de solos, fauna animal etc. não lembram em nada o bioma da "floresta amazônica", mas sim o do cerrado.

Uma vez que a aptidão agrícola dos solos e mesmo do clima das áreas de cerrado é muito superior à da floresta amazônica (no sentido estrito), dever-se-ia especificar melhor, nas informações do governo sobre desmatamento nesse Nortão, o que corresponde a áreas de cerrado e o que corresponde a áreas de floresta amazônica (no sentido estrito), uma vez que, do ponto de vista da análise de custo-benefício social, faz toda a diferença o destino produtivo da área desmatada. ${ }^{14}$

Finalmente, a perspectiva de análise adotada aqui permite-nos criticar o argumento, muito divulgado pela imprensa recentemente, de que embora seja verdade que a soja não esteja contribuindo diretamente para o desmatamento da Amazônia, indiretamente ela o estaria fazendo, já que estaria desalojando a pecuária das áreas propícias ao plantio da soja e forçando essa atividade a migrar para a Amazônia, em busca de terras mais baratas, com o conseqüente aumento do desmatamento. 15

Entretanto, é fácil mostrar que esse argumento não se sustenta. Em primeiro lugar, não é verdade que, ao ceder à soja áreas com pastagens degradadas, a pecuária esteja sendo substituída pela soja. Como vimos, é mais provável que a pecuária e a soja estejam "surfando" uma na onda da outra, com benefícios mútuos.

Em segundo lugar, se é verdade que a pecuária está se expandindo na Amazônia, não é necessário buscar a explicação disso na expansão da soja em outras regiões. Como aponta recente estudo do Banco Mundial, ${ }^{16}$ a expansão da pecuária na Amazônia tem trilhado dois caminhos: o primeiro, que vem ocorrendo na "fronteira estabelecida", reflete os próprios méritos do setor pecuário, que vem adotando a mais moderna tecnologia e obtendo alta tecnologia, sem qualquer apelo a subsídios públicos. O segundo caminho, ainda de acordo com esse estudo do Banco Mundial, vem sendo trilhado, há muito tempo, nas "frentes especulativas", pela pecuária de baixa produtividade, destruidora dos recursos naturais, e que, na realidade, nada mais é do que uma etapa no processo de grilagem de terra. Evidentemente, o crescimento dessas pecuárias não tem qualquer relação com a soja.

14 Esse cuidado não foi observado, entretanto, no anúncio do governo sobre o desmatamento nesse Nortão no ano de 2004 . A respeito do Nortão e de suas peculiaridades vis-à-vis à floresta densa, veja a interessante reportagem "Floresta ou Cerrado", publicada na revista Época de 7/6/2004.

15 Esta hipótese foi proposta por Michael Shean, um economista do USDA, no artigo “The Amazon: Brazil's Final Soybean Frontier", disponível no site do USDA (www.usda.gov/pecad). A mesma defesa encontra-se no "press release" intitulado "Soja versus Floresta: entenda a polêmica do estudo do IPEA", do Instituto Socioambental (www.isa.org.br). Ver também a matéria "Soja Empurra Boi para Floresta, Diz Estudo," na Folha de São Paulo de 17/03/05.

16 Margulis (2003). 


\section{A SOJA DEVE SER VISTA COMO AMIGA OU INIMIGA DA FLORESTA AMAZÔNICA?}

Essa discussão a respeito da maneira como a agricultura conseguiu expandir a área cultivada no Brasil no período recente leva-nos a considerar criticamente o grande receio existente no Brasil de que a expansão de soja venha, eventualmente, ameaçar a própria floresta amazônica.

É com base nesse receio que tem havido tanta resistência contra a melhoria de infra-estrutura de acesso a áreas envolvendo a floresta amazônica e outras regiões sensíveis do ponto de vista ambiental. Tal é o caso, especialmente, do asfaltamento da BR 163. Como se sabe, esse asfaltamento, independentemente do efeito positivo que ele terá sobre a atividade econômica no entorno da estrada, terá um impacto muito positivo sobre as regiões do Centro-Oeste (especialmente Mato Grosso), que hoje produzem soja e têm de transportá-la até os portos de Santos e Paranaguá; além disso, a Zona Franca de Manaus se beneficiaria graças à redução do custo de transporte de sua produção comercializada no Centro-Sul, e o próprio Nordeste ganharia, já que poderia importar alimentos do Centro-Oeste a custo menor.

A razão básica de por que não se deve temer o asfaltamento dessa rodovia é que, muito ao contrário do que se pensa, a viabilização da soja nessa região permitirá que a política de preservação ambiental se torne mais eficiente na consecução de seus objetivos. Com efeito, a viabilização econômica da produção de soja nessa região, graças à redução do custo de transporte, causará um aumento no preço da terra, tornando assim antieconômicas as atuais atividades predominantes na região, e que são responsáveis pelo atual uso predatório da floresta: 1) a agricultura itinerante, de baixo nível tecnológico e usuária do fogo para abertura de área; 2) a extração irracional de madeira; e 3) a atividade pecuária de baixo nível técnico e destruidora dos recursos naturais. ${ }^{18}$

Note-se que essas atividades que seriam deslocadas pela soja podem se transferir para outras áreas, mantendo-se, assim, o desflorestamento. Na realidade, essa nossa proposta deve ser entendida como parte de uma política mais geral do governo de se intensificar a política de "regularização fundiária" no conjunto da Floresta Amazônica, de maneira a se poder definir com precisão os direitos de propriedade da terra. Como se sabe, na ausência de titulação bem definida dos direitos de propriedade, o preço da terra, mesmo aquela terra mais adequada para o plantio da soja, simplesmente não refletirá essa superioridade da produção de soja e, portanto, esse mecanismo seletivo, via mercado, simplesmente não operaria. De qualquer maneira, pode-se esperar que, com a perspectiva de uso da terra na produção de soja, haverá maior incentivo para essa regularização fundiária nas regiões mais propícias para o plantio da soja, e melhor definição dos direitos de propriedade da terra, já que a produção de soja é inviável sem definição clara dos direitos de propriedade da terra. Em contraposição ao caso da soja, atividades como agricultura itinerante em pequena escala e na base de fogo, extração predatória de madeira e pastagens de baixa produtividade não fomentam essa busca da titulação das terras, e nem são inviabilizadas por custo de transporte alto. Assim, é uma grande ilusão achar que, ao não se asfaltar a BR 163, está-se preservando a floresta amazônica.

Além disso, uma atividade como a soja é mais passível de ser monitorada pelo setor público quanto ao cumprimento da política ambiental. Isso se deve, em primeiro lugar, à maior visibilidade

17 Para uma discussão bem completa dessa questão do asfaltamento da BR 163, veja as matérias "Problemas na BR-163 desafiam governo" e "Asfalto deve abrir rotas na região e reduzir fretes", a mbas publicadas no jornal Valor Econômico do dia 27.9.04, p. A4 e A5. Ver também a matéria no The Economist, já citado, e o artigo "Novas Perspectivas na Amazônia”, na revista Desafios do Desenvolvimento, Ano 1, no. 3 (Outubro de 2004, p. 42-51).

18 Essas atividades são as mesmas que Müeller (2003) classifica como "frentes de agricultura comercial tradicional”, "frentes de agricultura de subsistência", "frentes especulativas" e "frentes de pecuária tradicional”. Em contraste com todas essas, Müeller coloca as "frentes de agricultura comercial moderna", onde se encaixa a produção de soja. 
dessa atividade, o que permite que ela seja detectada mais facilmente e, em segundo lugar, porque uma atividade como a soja não dá lugar à atuação paternalista por parte de agentes do Estado (incluindo membros dos três Poderes), que geralmente deixam de cumprir a legislação ambiental quando os infratores são pobres. Um exemplo muito conhecido de como esse paternalismo estatal acaba impedindo que os objetivos da política ambiental sejam atingidos é a política de preservação ambiental das encostas do Rio de Janeiro (e da maior parte das cidades brasileiras): com efeito, ao se cumprir a legislação ambiental, proibindo-se a construção de habitações de classes média e alta em encostas do Rio de Janeiro, os preços dos terrenos nessas encostas tornaram-se praticamente zero, o que acabou por facilitar sua ocupação por parte da população pobre, com o surgimento das favelas, que não são combatidas - da mesma forma como as construções de classes de renda média e alta o são - pelos agentes do Estado responsáveis pelo cumprimento da legislação ambiental.

Mutatis mutandis, ao se procurar impedir o asfaltamento da BR 163, devido ao receio da expansão da soja, tudo o que se está conseguindo é, de fato, continuar viabilizando o atual uso predatório da terra, deixando de valer-se, essa política ambiental, de um importante aliado.

\section{O MODERFROTA E A EXPANSÃO RECENTE DA ÁREA CULTIVADA NO BRASIL}

Uma razão adicional para que a expansão da área plantada com soja nesse período mais recente tenha ocorrido por meio da conversão de pastagens foi o fato de que essa conversão ficou mais viável tecnologicamente, graças à entrada em operação, exatamente nesse período, do Moderfrota, que viabilizou uma grande expansão no estoque de máquinas e implementos agrícolas no Brasil.

Parece plausível admitir que uma expansão de área total plantada, na magnitude que ocorreu no Brasil no último triênio, só teria sido possível caso houvesse, como de fato ocorreu, uma maior disponibilidade de máquinas agrícolas, especialmente tratores. Assim, essa expansão de área teria sido uma combinação de disponibilidade de áreas de pastagens degradadas e maior disponibilidade de máquinas agrícolas - sem falar nas condições excepcionais de rentabilidade da produção de soja. À medida que, devido ao pisoteamento por animais, essas áreas de pastagens tenham se tornado muito compactadas, então a hipótese quanto ao papel estratégico do Moderfrota na explicação dessa expansão de área fica fortalecida.

O Gráfico 7 mostra a grande recuperação nas vendas domésticas de tratores agrícolas (de rodas e de esteira) e de colheitadeiras na década de 1990, interrompendo um longo período de virtual paralisia dos mercados domésticos dessas máquinas. Esse gráfico mostra que foi menor a retomada das vendas de tratores de esteira, o que é consistente com nossa hipótese de que o crescimento recente da área plantada não se baseou em abertura de novas áreas, mas sim em conversão de pastagens. O Gráfico 8, por sua vez, mostra a estreita correlação existente entre as vendas domésticas de máquinas agrícolas e os financiamentos via programas de empréstimos do BNDES. Na década de 1990, esses empréstimos começaram com a criação do Finame Agrícola, durante o governo Collor, no início da década, ganharam impulso com a criação do Finame Especial e, finalmente, com o Moderfrota propriamente dito, com os financiamentos iniciando-se no ano $2000 .^{19}$

19 Na realidade, foi a extensão do Finame à agricultura, com a criação do Finame Agrícola, que deu início a esse processo de recuperação do crédito de investimento, após a sua verdadeira derrocada, na década de 1980. Sobre isso, ver Brandão e Rezende (2004). 
Gráfico 7 - Evolução do número de máquinas agrícolas, 1970/2003 (em milhares)

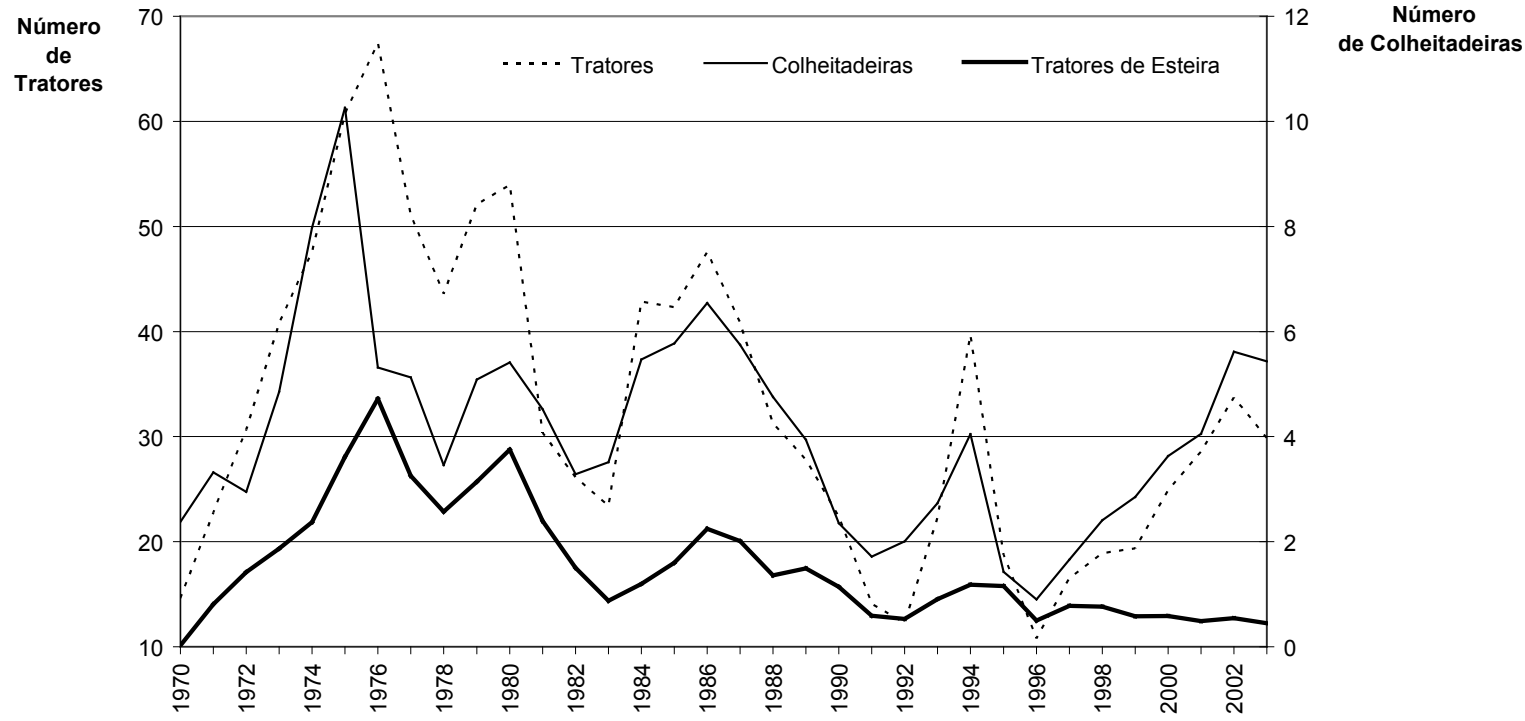

Fonte: Anfavea/Sindimaq/Abimaq.

Gráfico 8 - Empréstimos concedidos pelo Finame agrícola e vendas de máquinas agrícolas, $1990 / 2003$

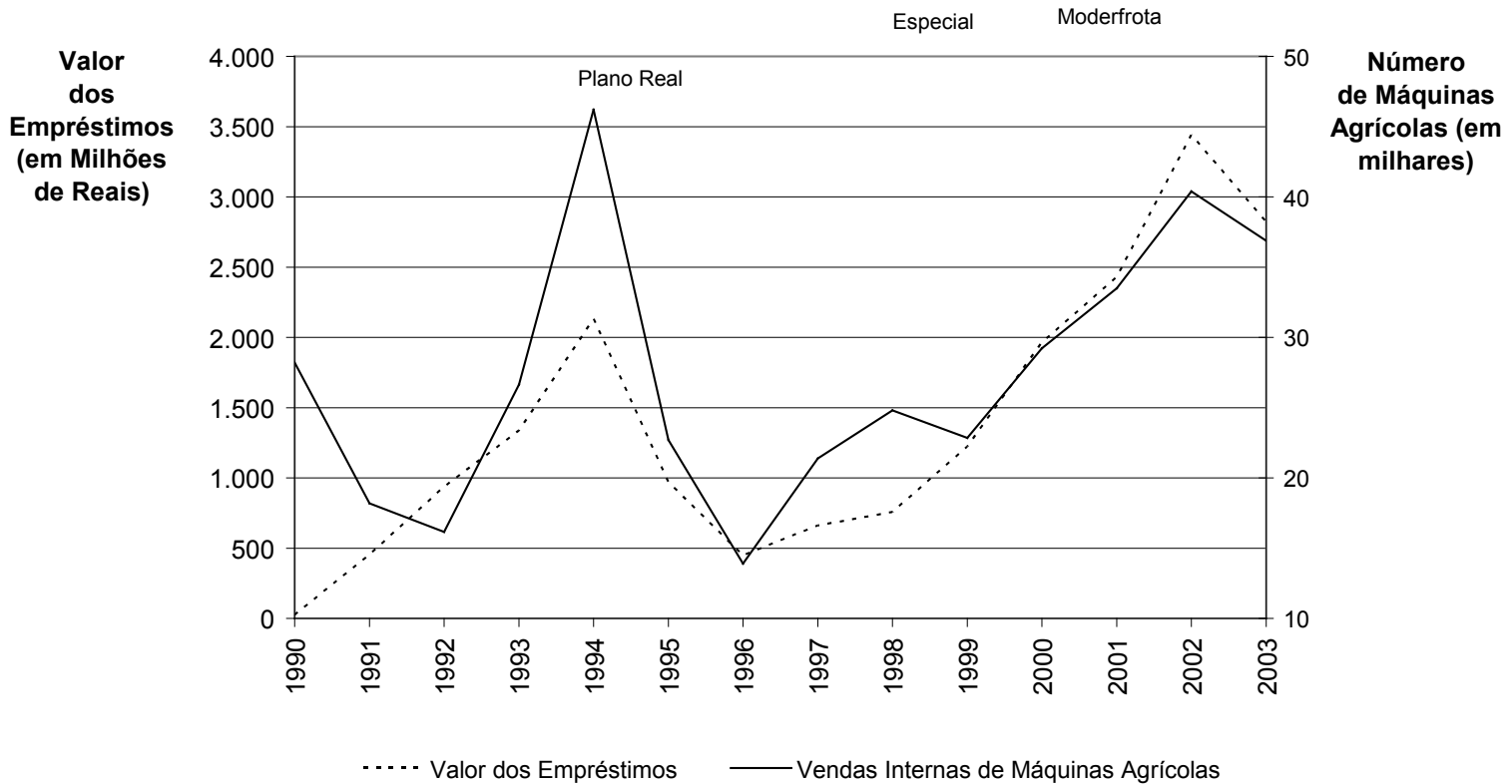

A este respeito, cabe mencionar a análise de Ferreira Filho e Costa (1999), em que esses autores sugerem a possibilidade de que o padrão de crescimento agrícola fortemente "intensivo", que tem se verificado no Brasil nas últimas décadas, tenha sido decorrente de uma restrição na disponi- 
bilidade de tratores, já que a falta de tratores teria dificultado a abertura de novas áreas de cultivo. Note-se, entretanto, que Ferreira Filho e Costa sugerem também que mesmo a agricultura "intensiva" requer máquinas, já que ela usa mais fertilizantes e outros insumos. Esses autores notam, ainda, que a rápida e generalizada adoção do plantio direto no Brasil pode ter estado associada a essa carência de máquinas no Brasil, já que essa técnica reduz muito a necessidade de tratores. Outra técnica poupadora de tratores é, segundo Ferreira Filho e Costa (1999), a aviação agrícola, que tem se expandido muito no Brasil.

Um outro possível efeito positivo do Moderfrota sobre o crescimento agrícola recente no Brasil é a menor dependência que, graças a esse programa, o setor agrícola passou a ter em relação ao mercado de trabalho agrícola - sobretudo em relação ao mercado de trabalho temporário. Com efeito, maior facilidade de acesso à máquina agrícola torna o setor agrícola menos dependente da mão-de-obra temporária, a qual, além de ter o seu custo para o agricultor magnificado pela legislação trabalhista e pela tributação excessiva, padece dos problemas conhecidos, do ponto de vista dos empregadores agrícolas, de baixa qualificação dessa mão-de-obra temporária e incerteza quanto à sua oferta.

Uma questão adicional para pesquisa futura é saber se o Moderfrota, além de contribuir para uma maior expansão agrícola, não está também contribuindo para o aumento da concentração na agricultura, devido ao menor acesso a esse programa por parte dos pequenos agricultores, seja devido à maior restrição de crédito, seja em decorrência da indivisibilidade dos equipamentos. Entretanto, por mais interessantes que sejam esses temas, eles terão de ser deixados para discussão em trabalho futuro dos autores.

\section{SUMÁRIO E CONCLUSÕES}

Este trabalho procurou contribuir para a análise do processo de crescimento agrícola recente brasileiro de duas maneiras principais. Em primeiro lugar, procurou-se mostrar de que maneira esse crescimento agrícola foi afetado pela mudança da política cambial de janeiro de 1999, de um lado, e pelo comportamento dos preços agrícolas internacionais, de outro lado. Em segundo lugar, procurou-se chamar a atenção para a mudança que ocorreu nos últimos três anos agrícolas no que se refere ao comportamento da área plantada, já que esta última cresceu de forma explosiva, rompendo com o padrão anterior em que a área cultivada permanecia constante e o produto agrícola crescia por meio de aumento da produtividade da terra.

À primeira vista, essa explosão da área cultivada poderia sugerir que a agricultura brasileira tivesse voltado a crescer como antigamente, pela via "extensiva” (no sentido ricardiano). Entretanto, como o trabalho procurou sugerir, essa expansão de área cultivada muito provavelmente se deu, preponderantemente, ainda no âmbito de uma vasta "fronteira interna", formada por um estoque de áreas de pastagens "degradadas", que encontraram na sua conversão (temporária) à soja a maneira mais adequada de se renovarem, ou seja, de se tornarem capazes de viabilizar uma lotação maior de animais nas propriedades. Note-se que, conforme foi apontado, não se exclui a possibilidade de que áreas virgens de cerrado também tenham servido de base para essa expansão tão rápida da área plantada com soja. Porém, devido às limitações agrícolas dos solos de cerrados, a utilização de áreas virgens de cerrado terá sido, muito provavelmente, numa escala modesta. Quanto às áreas virgens de floresta amazônica, tratar-se-ia, simplesmente, de uma mágica de se conseguir, num período tão curto, realizar todas as operações envolvidas na conversão de uma área de floresta virgem em área cultivada de soja. 
Não se exclui a possibilidade de que áreas novas de cerrado ou mesmo de floresta amazônica tenham iniciado (mas não terminado), no período sob análise, o seu processo de conversão em terra apta para a produção de soja. Quanto maior a área em processo, assim, de incorporação à atividade agrícola, maior poderá ser, no futuro, a elasticidade de expansão da soja em conjunturas de preço favoráveis.

Ao sugerir que essa expansão da área com soja se tenha dado, preponderantemente, por meio desse mecanismo de conversão de pastagens, e não via incorporação - no mesmo período - de áreas virgens (seja de cerrado, seja de floresta amazônica), este trabalho pretende mostrar que as possibilidades de expansão da produção de soja no Brasil são muito amplas, e não se deve temer que, dessa expansão, surja uma nova ameaça à preservação do meio ambiente, seja no cerrado, seja na Amazônia. Na realidade, este trabalho vai mais longe, e sugere não haver razões para se temer que a expansão de área com a soja ameace a política ambiental brasileira. Segundo o argumento defendido neste trabalho, a melhoria de infra-estrutura de transporte (como exemplificado pelo término do asfaltamento da BR 163), juntamente com uma melhor definição dos direitos de propriedade nas regiões afetadas, deverá, ao viabilizar a expansão da soja, facilitar, e não dificultar, a execução dessa política.

\section{BIBLIOGRAFIA}

Abramovay, R. Moratória para os cerrados - Elementos para uma estratégia de agricultura sustentável. Consórcio Atech/Museu Emilio Goeldi/Procan, Agenda 21, 1999, mimeo.

Brandão, A. S. P.; Rezende, G. C. Brazilian agriculture in the 1990s and ahead: the role of government programs to support development and challenges ahead. Trabalho preparado para OECD, 2004.

Brandão, A. S. P.; Rezende, G. C.; Marques, R. W. C. Crescimento agrícola no período 1999/2004, explosão da área plantada com soja e meio ambiente no Brasil. Rio de Janeiro: IPEA, Texto para Discussão no 1062, Janeiro de 2005.

Cunha, A. dos S.; Müeller, C. C.; Alves, E. R. A.; Silva, J. E. Uma avaliação da sustentabilidade da agricultura nos cerrados. Brasília: IPEA, 1994 (Relatórios de Pesquisa, nº 11).

Ferreira Filho, J. B. de S.; Costa, A C. F. de A. O crescimento da agricultura e o consumo de máquinas agrícolas no Brasil. Trabalho apresentado no XXXVII Congresso Brasileiro de Economia e Sociologia Rural, realizado em Foz do Iguaçu, Paraná, em 1999.

Ferreira Filho, J. B. de S.; Alves, L. R. A.; Gameiro, A. H. Algodão: alta competitividade no Brasil Central. Agroanalysis, v. 24, n. 3, p. 24-27, mar. 2004.

Margulis, S. Causas do desmatamento da amazônia brasileira. Brasília: Banco Mundial, 2003.

Müeller, C. C. Expansion and modernization of agriculture in the cerrado - the case of soybeans in Brazil's Center-West. Brasília: Departamento de Economia, Universidade de Brasília, Outubro de 2003.

Rezende, G. C. Ocupação agrícola, estrutura agrária e mercado de trabalho rural no cerrado: o papel do preço da terra, dos recursos naturais e das políticas públicas. In: Helfand, S. M.; Rezende, G. C. (eds.), Região e espaço no desenvolvimento agrícola brasileiro. Rio de Janeiro: IPEA, 2003, p. 173-212.

Romeiro, A.; Reydon, B. P. (coords.), O mercado de terras. Brasília: IPEA, mar. 1994 (Estudos de Política Agrícola, 13).

Shean, M. J. Brazil: future agricultural expansion underrated. Washington: Production Estimates and Crop Assessment Division, FAZ/USDA, Jan. 2003.

Torres Jr., A. de M.; Rosa, F. R. T.; Nogueira, M. P. Mais boi em menos pasto. Agroanalysis, p. 37-39, agosto de 2004. 